\title{
Article \\ The Quest for Gender-Sensitive and Inclusive Transport Policies in Growing Asian Cities
}

\author{
Marie Thynell \\ School of Global Studies, University of Gothenburg, 40530 Gothenburg, Sweden; \\ E-Mail: marie.thynell@globalstudies.gu.se
}

Submitted: 15 October 2015 | Accepted: 3 March 2016 | Published: 7 June 2016

\begin{abstract}
In cities all over the world, growing numbers of women are working or studying further away from home than ever before. This article presents policies by the World Bank and recommendations by the United Nations to improve conditions for women's mobility in cities. Although these stress different factors affecting women's experiences of traffic and transport, they all agree about the importance of enabling women's mobility. However, gender-sensitive policies have been largely unsuccessful. This article presents examples of conditions for women in New Delhi and other rapidly growing Asian cities that illustrate how gender norms operate. This study uses the perspectives of development research and gender studies to examine economic and political initiatives and the way women act and interact with transport in local contexts. It facilitates critical reflection upon existing transport policies and suggests 'how' women's needs may be effectively addressed. More in-depth knowledge about women's needs and the problems they face when travelling will be useful for designing of policies that address more than simply the harassments of women. More inclusive urban access would enhance conditions for women and enable them to make choices according to their needs. In this way, social science and policy will cross-pollinate one another.
\end{abstract}

\section{Keywords}

development banks; development research; gender; mobility; policy; public transport; sustainable transport; transport equality; United Nations; urban Asia

\section{Issue}

This article is part of the issue "Transport Policy and Social Inclusion", edited by Miriam Ricci, Graham Parkhurst and Juliet Jain (University of the West of England, UK).

(C) 2016 by the author; licensee Cogitatio (Lisbon, Portugal). This article is licensed under a Creative Commons Attribution 4.0 International License (CC BY).

\section{Introduction}

An increasing number of families are dependent on female breadwinners and greater numbers of women are now working further away from home than ever before in history. The conditions for women in cities around the world vary and the way they have to "juggle domestic responsibilities, marital relationships and paid work" is affected by various constraints (Tacoli \& Satterthwaite, 2013, p. 6). In many cities women spend a large part of each day in public space, travelling on buses and trains or walking and bicycling on roads.

Modern transport facilities are seen as a prerequisite for cities to develop and prosper and for families to enjoy a reasonable quality of life. In recent years, alongside urban modernisation and gentrification processes, traffic and transport systems have undergone dramatic change in order to meet the mobility needs of people and goods. In most cities, large businesses and services have become better connected with the help of both public and private investment but the situation for low-income families or those who live in peripheral areas of cities have benefitted far less. From a gender perspective, it is also evident that traffic and transport policies and infrastructure have not responded equally to women's and men's mobility needs (Moser \& Moser, 2005; SIDA, 2005). It is widely recognized that modern mobility is not inclusive and that many suffer 
from problems with access to work, healthcare, leisure activities and social services (Lucas, 2004).

Urban growth puts great pressure on the infrastructure to accommodate greater numbers of people. Transport problems in the cities of emerging economies often seem overwhelming or even insurmountable (Thynell, 2003). National and local policies vary widely but in general they stress the role of transport in economic development and modernization, as illustrated by the policies in China and Vietnam (Thynell, Tran, \& Schlyter, 2010). Urbanization is often associated with increasing opportunities for women and girls, but "most urban women experience profound disadvantages compared to men in their daily life" (Tacoli \& Satterthwaite, 2013, p. 3). With its Western technical background, the transport sector tends to become gendered through various mechanisms relating to socio-economic conditions, traditional ways of life, religion, women's legal status, their position in the labour market and their role in decision making (Thynell, Tran, \& Schlyter, 2010). Since few women are employed in the transport sector in the developing world, masculine norms tend to become invisible and taken for granted. According to the political scientist Kronsell "institutions that historically have or are dominated by male bodies reflect masculine norms which have normative power over its agenda" (Kronsell, 2005 in Kronsell, 2015, p. 7).

Urban journeys are not ends in themselves but are tools that women may use to improve their chances of participating in society and perhaps enhancing their quality of life.

This article focuses on the transport situation faced by women in rapidly growing Asian cities in which the number of motor vehicles is increasing. It explores this from the perspective of development and gender research. A gender analysis of women's travel behaviour, needs, priorities, opportunities and constraints and factors such as income, age, health and ethnicity all need to be understood in the local context in order to inform the design of appropriate transport policies (World Bank, 2010).

In 2015, the United Nations (UN) launched the Sustainable Development Goals (SDGs) and drew attention to the pressing need for inclusive mobility. Goal number 11 is called 'Make cities inclusive, safe, resilient and sustainable' and transportation is a key development issue described in target 11.2: "By 2030, provide access to safe, affordable, accessible and sustainable transport systems for all, improving road safety, notably by expanding public transport, with special attention to the needs of those in vulnerable situations, women and children, persons with disabilities and older person"' (United Nations Chronicle, 2015). However, although this points to the crucial role played by transport in fulfilling the SDGs, ministries of Transport and Environment and city administrators often find it difficult to translate international recommendations into effective policies.

Most agencies lack the requisite knowledge about local needs to address the gender aspects of mobility (World Bank, 2010), and they tend also to lack the capacity to guide governments in their efforts to establish 'transport equality'. Journeys are embedded in socio-spatial contexts and unsubstantiated beliefs about social inequality or gendered mobility are not helpful for designing effective policies. The current knowledge gap needs to be bridged and tools will have to be designed using information about how women act and interact with transport systems, the natural environment and the socio-economic and traditional context. This means that experiences gained from parts of the world that became motorized earlier, such as the US or Europe, are not necessarily applicable to developing Asian countries.

\subsection{The Purpose and the Challenge of Women in Urban Mobility}

The complex nature of mobility requires that we look beyond physical factors of traffic and transport and explore 'how' and 'why' the gender order influences women's mobility. The purpose of this study is to explore the conditions for women's mobility in growing Asian cities using three kinds of gender-sensitive perspective: research, the UN and the development banks. The study also aims to discuss how well-informed policy may facilitate women's mobility in rapidly changing and developing Asian cities.

The challenges associated with urbanization (climate change, growing inequality, rapidly changing cities) have introduced new understandings of the importance of urban development and traffic conditions in developing countries. Today's focus on sustainable development opens a window of opportunity for considering new ways of proceeding, and the notion of sustainable transport includes the issue of 'transport equality', which means considering road safety and security factors that are often of particular concern for women.

The gender mainstreaming of transport systems is at the core of several transport recommendations made by the UN and the development banks. Gender has become integrated into development research together with the notions of empowerment/disempowerment, strategic life choices, resource management and agency. Achieving transport equality involves ensuring that the perceptions, interests, needs and priorities of both women and men are given equal weight in planning and decision making (SIDA, 2005).

This article begins by introducing some earlier research and fundamental gender considerations that relate to mobility. These will be returned to in the concluding discussion. The World Bank and the UN have 
developed various initiatives to address the problems observed in today's transport systems, which are seen to be permeated by masculine norms. The objective of the United Nations Panel on Climate Change is to meet the challenges of vulnerability, adaptation and mitigation (United Nations Intergovernmental Panel on Climate Change, 2014). Earlier gender-sensitive initiatives that targeted various aspects of women's roles in development (poverty reduction, social cohesion, sustainability) have also tended to share a concern with women's mobility and equal access in cities, albeit for varying reasons. However, this kind of initiative has thus so far failed to create equality of access to transport or enhanced women's urban mobility in Asia. The possibilities and obstacles for achieving more inclusive and female-friendly transport systems will also be discussed.

\subsection{Earlier Research}

Studies of women in developing countries emerged as a research field decades ago (Moser, 1989). The points of departure were several. Firstly, there was interest in the effects of freedom from colonialism and women's liberation. Secondly, researchers explored the social impact of the structural adjustments programmes that were implemented in emerging markets in the 1990's. Thirdly, there was interest in the second wave of feminism, as manifested in the UN women conferences (Nairobi, Beijing). Fourthly, researchers examined the discourse of civil society, participation and poverty reduction programmes and they critiqued development practices and rights. This is illustrated in the work of a number of scholars on topics such as poverty reduction programmes and development (Eyben, 2012), women's empowerment frameworks (Longwee, 1995), on the undoing of internationalized oppression (see Rowland, 1997) and on the ability to make choices (see Cornwall, 2004; Eyben, 2004; Kabeer, 2001).

Urban research dates back to authors such as Henri Lefebvre (1982) and David Harvey. In his book Social Justice and the City, Harvey (1978) claimed that the principle of justice has profound relevance for urban development and for the link between spatial form and social processes. He noted that transport plays a crucial role in this by removing barriers such as time and distance for equal access to opportunities.

The differences in men's and women's travel behaviour and attitudes were recognized long ago. A number of scholars in geography, sociology, feminist and urban studies have added to the growing body of findings and highlighted the cross-cultural features of gendered mobility. The notion of inclusive mobility refers to physical, social and culture aspects of travelling (Hanson, 1996, 2010). The values that guide attitudes and behaviour may therefore differ radically between continents. Mobility also refers to the ability to move between different activities sites, such as between home and school (Hanson, 1996, p. 4). The situation for women in relation to transport in rapidly motorizing and growing cities is still an emerging area of research but there is an extensive body of literature from developed countries that became motorized early on. However, mobility is a complex phenomenon and findings from the US, the Nordic countries or European countries are not necessarily transposable to Asia. Some alternative contributions to the literature have been made by authors such as for instance Adeel, Yeh and Zhang (2016), Grieco (2009), Grieco and Urry (2011), Peters (2001, 2011), Raje, Grieco, Hine and Preston (2004), Tiwari (2014), Turner (2012), Uteng (2011), and Wang and Qin (2015). The report from the conference 'Poverty and Mobility in the Context of Asia' refers to the work of organizations that are engaged in women's mobility and various findings that engage in theories, practices and ethics that are becoming of growing concern to politicians in Asia (Bisan, 2010).

The following section presents some further background to the shifting needs of mobility.

\subsection{Mobility Fundamentals: Gendered Patterns}

The major reason that women travel is to get to work or a place of education (Tara, 2011). Their travel behaviour therefore relates to the location and forms of available employment-formal, informal, part-time, unskilled, self-employment (Hanson, 1996; Hanson \& Pratt, 1995). Research has also shown that variables such as gender and employment status have a greater impact on the travel behaviour of individuals than does social class (Hanson, 1996). Work opportunities may be decisive for the number of journeys undertaken per week, the distance travelled, the means of transport chosen and the cost of travel. Other factors that influence women's mobility are responsibility for caring for children or elderly or infirm relatives (Camstra, 1996; Hanson, 1996).

Women often make more frequent but shorter journeys than men and often at off-peak hours. Notably, the gendered order is related to household practices, their position in the labour market and their access to vehicles (Law, 1999; Rosenbloom, 2004; SIKA, 2007). All these fundamentals are mainly from studies carried out in the US or Europe. Another study showed that women are more critical of car use then men are (Linden, 1994).

The Sustainable Development Goal 11 states "When compared to men, women move about cities at different times, for different reasons, in different ways, and have fewer financial resources; they are less able to afford many of the transportation options available to them" (United Nations Chronicle, 2015). In India, in general, women have lower incomes and suffer from spatial constraints and less mobility than men since costs of safe and secure transport are too high for 
them (Tiwari, 2014). In Delhi, for example the relocation of squatter communities to the outer periphery of the city has been especially damaging to women's ability to earn a living. Female unemployment in these locations rose by $27 \%$ compared to $5 \%$ for men (Moser \& Peake, 1987).

To save money, women may choose to walk instead of taking a bus and this means that poor women are more affected by distance. In general women depend more on public transport than men do. Women often try to work closer to home than men do, even at the expense of better work or higher incomes (Turner, 2012). Uteng (2011) states that dismal road conditions affect all users but there may be differences in what possibilities people have to handle the problems.

The next section presents some local features having an impact on women's options and behaviour.

\section{Urban Journeys in Rapidly Growing Asian Cities}

An ever-growing proportion of the world's population are living in cities. Another 2.5 billion people are projected to add to the world's urban population with nearly 90 percent of the increase concentrated in Asia and Africa. India alone is expected to double the number of city dwellers by 2050, with some 404 million more people living in its cities whereas the cities in China are likely to grow with 292 million (United Nations, Department of Economic and Social Affairs, 2014 , p. 1). Although greater urbanization is desired by dominant global actors, housing, infrastructure and services are rarely planned to meet the increasing demands. Globally, some 828 million people are living in urban slums and the number keeps rising (United Nations, 2015). The Asian Development bank notes that "almost $25 \%$ of Asia's urban population is poor, and the rate is increasing, as there is a continuous influx of poor people into cities" (Asian Development Bank, 2014). In Cambodia, Bangladesh, the Philippines and Mongolia, some $40 \%$ of the population subsist below the poverty line.

Despite their historical, economic, sociological, political, and cultural disparities, cities such as Jakarta, Hanoi, Delhi, Mumbai, Metro Manila, Bangkok, Kuala Lumpur and Beijing all suffer from worsening traffic congestion and transport problems (Vasconcellos de Alcantara, 2001), air pollution and accidents (Wismans et al., 2015). Transport difficulties usually pose less of a problem for men while women frequently state that their needs are not being met (World Bank, 2010). Growing cities mean longer distances and more time spent on roads. Informal or newer parts in cities often suffer from lack of appropriate infrastructure and roads can be dangerous. Streets are often too narrow, badly maintained, have poor drainage and lack traffic management. In Shanghai, 7.4 percent of urban space is occupied by roads, in Seoul 20 percent, in Paris 25 percent, whereas, in Calcutta, Xian and Hanoi only 6 percent of space is occupied by roads (Thynell, Tran, \& Schlyter, 2010).

It has been predicted that the demand for transport facilities is set to increase considerably but insufficient planning and weak law enforcement means that informal transport operators often tend to fill the gap and are likely to do so more in the future. Urban mobility will continue to be a major problem (Thynell \& Wolmar, 2014) and more women are likely to be commuting in the future. Urban geography, the technical and natural environment, and social-cultural conditions also influence women's travel options and choices. In Dhaka, for instance, 75 percent of the people on the streets are men and amongst other things this, reflects the lack of safety and security for women (Kahn, 2009). Some common features of Asian cities are:

- Bicycles play a pivotal role along with other nonmotorized vehicles (NMVs) and motorcycles.

- Non-motorized means of transport are seldom planned for or regulated and maintenance of footpaths, bus stops and streetlights is often lacking.

- A large proportion of women depend on public transport (formal and informal), which is often inefficient, uncomfortable, dirty, unreliable, poorly maintained and unsafe.

- Rates of traffic-generated air pollution and noise are soaring.

- There are high rates of traffic injuries and fatalities and pedestrians, passengers (all ages), drivers of NMVs and motorcyclists are particularly at risk (Wismans et al., 2015).

Access to a variety of destinations is important for women to be able to cope with the mixed demands upon them in providing for their families. Walking and cycling are both affordable and accessible ways for the vulnerable, including women and the poor, to move about cities. But 65 percent of the 1.2 million deaths that occur each year worldwide due to road accidents involve pedestrians and 35 percent of those deaths are children (Short \& Pinet-Peralta, 2010). Unsafe roads and the price of travel are often strong deterrents for women to use transport. Globally, six out of ten of the world's poorest people are women (United Nations Development Programme, 2013) and this influence their choices in such a way as to make them less mobile than poor men. This means that jobs and social services are becoming more accessible to men only.

In some Muslim countries, men and women travel separately in taxis and on public transport. Some big cities offer women-only services, or 'pink solutions' and provide buses or metro cars exclusively for women and children. The separation of sexes in public transport was introduced on a private railway on Manhattan 
some 100 years ago. It is now used during rush hours in mega-cities such as Mexico City, Cairo, Tehran, Dhaka and Tokyo. However, while 'pink solutions' may solve acute problems of harassment, humiliations, drugdealers, purse-snatchers and so on, they also reinforce the gender order and "perpetuate divisions and differences between the sexes rather than comprehensively addressing the deep rooted gender biases inherent in current transport planning and policy making" (Peters, 2013, p. 35).

The following section looks more closely at women in public transport and in public space.

\subsection{Public Transport and Public Space: Gendered Arenas}

Public transport is a crucial element of sustainable transport and of efforts to reduce urban inequality. The social parameters of public transport policies may be summarized as the five A's: Affordability, Availability, Acceptability, Accessibility (Carruthers, Dick, \& Faukar, 2005) and Appropriateness (Thynell, Punte, \& Arora, 2009). Accessibility designates the number of opportunities available within a certain distance or travel time, and appropriateness is related to local meanings and cultural gender norms. A nearby bus stop might not be accessable because of insecure streets, heavy traffic, a lack of shelter from the sun or rain or lack of seating. Hence, accessibility is related to the overall transport environment and it begins with the public transport facilities themselves and how policy and planning respond to gender norms. Structural discrimination against women and children from low-income families means they are more exposed to risks when moving around the city. And "for a very large number of women in urban areas the constant threats, from verbal harassment to outright violence whenever they leave the home are an unwelcome reality" (Tacoli \& Satterthwaite, 2013, p. 5).

Women's use of public space or public transport is often contested. A study from Delhi shows that 85 percent of women reported having faced harassment or violence in public space (Jagori \& UN Women, 2011, p. 14). In 2012, the rape and murder of a woman on a bus in New Delhi brought the media's attention to the traditional treatment of women (Roychowdhury, 2013) in public transport. In New Delhi, 54 percent of women reported feeling unsafe when using public transport (Jagori \& UN Women, 2011, p. 16). Another problem is that the frequency of bus services, route options and stop locations may not respond to women's needs. Since the average salary in New Delhi for a woman working in the informal sector is low (between 10-100 Euros according to unconfirmed information from $\mathrm{Na}$ tional Survey Sample Organization and Indian Association for Women's Studies), the affordability of public transport is a major concern for women. For passen- gers without travel options-so-called captive riders - the fare price, safety, reliability and information about departure times are important (Carruthers et al., 2005). To avoid high commuting costs families sometimes try to stay in slum settlements in the city centre.

\subsection{Other Problems on the Roads}

The use of roads reflects broader economic and social trends and in Asian cities. It is common to find women working along the roadside selling, cooking, cleaning the streets or working on road construction. Their vulnerability is exacerbated by malnutrition and lack of healthcare. The absence of public lighting, poor infrastructure, lack of toilets or bus stops and car parks that lack guards all increase feelings of insecurity. There may also be little accommodation for the needs of pedestrians. Weak law enforcement may also make public space insecure, particularly for women. Other problems include:

- Long travelling distances and long hours spent on roads.

- A wide variety of modes of transport.

- Irregular bus and train services. Overcrowded vehicles, congestion, careless drivers, poorly constructed bus stops.

- No traffic priorities (lanes for buses, separation for NMVs or pedestrians).

- Unsynchronized routes and networks that are not adapted to fit the place of activities.

- Excessive levels of noise and pollution (Carruthers et al., 2005).

In Western cities that became motorized early on policy and planning has reduced many of the risks that women experience in rapidly growing cities or informal urban areas. In some cases, a shift towards sustainable transport has already begun. The following section presents some gender-sensitive approaches to these issues from researchers and international actors.

\section{Discussion of Policy Framework}

This section presents contributions from three international actors. The first is the research approach based on feminist epistemologies and development research. The second is that of international banks in the sector of traffic and transport systems and, the third is the UN recommendations and their potential influence on state policies and international organizations. These perspectives act and interact in asymmetric ways.

\subsection{Perspectives in Development Research}

At the Fourth UN World Conference on Women in Beijing in 1995, President Zemin stated: "Attaching great 
importance to the development and advancement of women, we in China have made gender equality a basic state policy in promoting social development....We are resolutely against any form of discrimination against women" (Du \& Kurz, 2003). This prompted the interest of researchers in the problems underpinning inequality and in how to strengthen the position of women relative to men. A number of initiatives were taken but they ignored the embeddedness of the problems in local socio-cultural relations. A framework emerged that included the visions, needs and interests of both women and men. Studies were undertaken of the problem of equal rights for women and girls-regardless of age or economic status were undertaken (Chant \& Sweetman, 2012; Kabeer, 2005; Linden, 1994; Moser, 1989, 2006; Roberts \& Soederberg, 2012). The commitment and co-operation of men were seen as critical for transforming gender relations: "Gender and development should also involve the inclusion of other social actors vital in supporting the empowerment of womenincluding, most importantly, men and boys" (Moser \& Moser, 2005). Structural inequality was seen as a relational problem that must be addressed by all stakeholders: institutions, governments and society at large (Moser \& Moser, 2005). Empowerment meant that "focus was not centred on women, but on the social, political and economic relations as well as the structures and processes that create, reinforce and sustain inequality on one hand, and, the result in different outcomes for both women and men on the other" (African Development Bank \& African Development Fund, 2001). Feminist epistemology and development research use methods suitable for in-depth study of the social structures and the geographical, cultural and economic factors that shape modern transport conditions. Scientifically informed policies may make it possible to improve the position of women relative to men in public space and in the transport system. However, we are still very far from making use of these tools in rapidly growing and changing cities in Asia.

According to Western scholars of International Relations, the achievements at the Beijing conference were later marginalized and replaced in 2000 by the Millennium Development Goals. The shift in 'aid modalities' meant that gender issues became overshadowed by concerns with efficacy, management and corporate interests as governments changed policies (Eyben, 2004). Another explanation proffered for why interest in transport equality waned was that it became eclipsed by the post-9/11 security agenda and the War on Terror (Marchand, 2009).

The hypothesis here is that traffic and transport systems are shaped by male users and masculine norms. In only a few countries do women actively influence or work in the transport sector. The nature of modern mobility is beginning to become the topic of debate in some countries. However, in the huge Asian economies of China, India and Indonesia, embedded norms about transport in relation to growth and prosperity have not yet been called into question. Gender studies are not included in the university programmes of engineering or urban planning. Locally developed tools to measure a project's impact on gender inequality or the gathering of sex-disaggregated data remain unavailable at ministries and in planning departments.

The complex interplay between socio-economics and the physical and technical environment mean that quantitative and qualitative studies from different socio-economic contexts are needed to enhance our understanding of how inequality and gender are variably constituted. It has been found, for instance, that the choices men and women make about transport do not necessarily simply reflect economic status, access to cars or a particular feature of the transport system. "It is necessary to qualify this statement, while the transport behavior of women and men are chosen, the choices occur within a normative framework, where different transport uses relate to masculine and feminine identities and norms of mobility" (Kronsell, Smidfelt-Rosqvist, \& Hiselius, 2015).

Other surveys stress the gender differentials in travel behaviour in terms of $\mathrm{CO}^{2}$ emissions and show that women tend to choose less polluting forms of transport than men. It is well-known that public transport is often preferred by women if it is safe. Paterson (2007) explains this as a result of norms of masculinity-freedom and autonomy being related to the ecological and cultural economy of the automobile. In other words, motorized vehicles have become part of masculine identity and what it means to be a modern man. Mobility is therefore associated with identity. Transport equality is partly about the realization of female values since the way they are reflected in transport behaviour is known to be environmentally beneficial (Kronsell et al., 2015). There thus appears to be a transformative potential in the values evident in women's mobility choices. This could be used to enhance transport equality and sustainable transport. The mainstreaming of women's needs in transport policies and urban planning could enhance women's safety in the transport system and in public space more broadly. This could give rise to greater cultural acceptance of mobile women and thus contribute to women's empowerment (Uteng, 2011).

We now turn to policy responses by some of the influential global economic and political actors: The World Bank and the UN.

\subsection{Development Bank Policies}

Motorized mobility is a global business in which large financial institutions have invested. From 2005 to 2009 the Asian Development Bank (ADB) invested 11.3 billion US dollars in Asia (Lohani, 2010). By 2013, another 
2.5 trillion US dollars were needed in Asia alone (UNCRD, 2013). The development banks have recognized that "creating opportunities for women is clearly smart economics" (Wolfowitz, 2006) and several policies have consequently been launched. For instance:

"For the World Bank Group, promoting gender equality is a central component of fighting poverty. Therefore we need to focus on mainstreaming gender in non-social sectors that support shared growth-such as infrastructure, energy and transport-and improve data collection to understand women's participation in these sectors." (Wolfowitz, 2006)

The poor transport facilities found in many rapidly developing cities represent significant losses in terms of economic opportunities. Although developing countries often fail to manage their urban transport needs, the funding of transport systems by the World Bank or other institutions, is generally highly valued as a spur for economic growth and urban development. These investments are often seen to bring greater benefit to the poor than to the wealthy (Vasconcellos de Alcantara, 2001). Good, safe transport would improve the prospects for a large number of women and low-income families. However, if policy is to be based upon scientific knowledge, local surveys are required to gather information about women's travel behaviour, needs, priorities, opportunities and constraints and to take into consideration factors such as income, age, disabilities, ethnic minorities (World Bank, 2010). The World Bank aims to achieve poverty reduction by enabling better urban access and supporting transport projects that may generate employment opportunities and in so doing reducing poverty (Gannon \& Liu, 1997).

However, the ADB recognizes that investments alone will not improve welfare, "we need complementary measures to help translate growth into better living standards. The way to do that is to include those on a lower income in the growth process" (Vasconcellos de Alcantara, 2001). The ADB thus opens the way for inclusive social and gender policies. In the ADB strategy for 2013-2020, the objective of achieving gender equity was defined as a major incentive for changing public transport systems so as to unleash their socioeconomic potential. In Asia, there are around 1.7 billion people who live in poverty and are unable to access the essential goods, services, and opportunities to which every human being should be entitled (Vasconcellos de Alcantara, 2001). Improved access to good urban transport could make a significant difference. Later on United Nations Chronicle stated that "a welldesigned transportation system that supports walking, cycling and public transit use will allow all people to fully participate in community life and creates safer, cleaner, healthier, and more social places" (2015).
The World Bank's 'Smart economics' has reduced the role of women to that of facilitating economic growth. This means that "women are enlisted as foot soldiers to serve in battles whose aims are not related directly to their interests" (Cornwall \& Molyneux, 2006). This economic and top-down perspective overlooks the complexity of the relational and structural factors inherent in the transport sector. 'Smart economics' has therefore been viewed as the "business case for gender equality [that is] concerned with building women's capacities in the interests of development rather than promoting women's rights for their own sake.... To increase equality in traffic and transport the primacy of gender justice and rights will have to reasserted in a manner which eschews the notion that it is only worth investing in women if they can 'fix the world'” (Roberts \& Soederberg, 2012, pp. 527, 954).

\subsection{The UN, Sustainable Transport and the Bali Declaration}

Rapid motorization and a dramatic increase in the need to transport goods and people in the last century meant that priority was given to solving technical and economic transport problems. However, the UN has also introduced the goal of developing 'sustainable transport' systems with low carbon emissions. The discourse this has given rise to has thus focused far more upon environmental, technical and economic problems than social factors. The "basic access needs of individuals and societies to be met safely" (Litman, 2006) requires greater knowledge and elaboration so that human health and environmental wellbeing are dealt with in tandem. Equality of access and gender mainstreaming must therefore be included alongside affordability and efficiency as the goals of healthy economies (Ki-Moon, 2013).

In 2013, the UN Secretary-General, Mr. Ban KiMoon, declared: "Transport is a key building block for sustainable development. Access to goods and services through efficient means of transport and connectivity is essential for poverty reduction. On a global scale it is essential to design and build safe and environmentally friendly transport infrastructure and to minimize vulnerability to climate change and natural disasters" (KiMoon, 2013). The Bali Declaration (2013) represented a formal recognition of the need to develop transport systems based on zero tolerance of congestion, pollution and traffic accidents. This declaration also called upon countries to devise and implement appropriate policies, programmes and enforcement measures to protect their citizens, environment and property while strengthening socio-economic sustainability. Topics include: a) Public health, b) Land-use planning, c) Environment and people-friendly urban transport infrastructures, d) Public transport planning and transport demand management (TDM), e) Non-motorised 
transport (NMT), f) Social equity and gender perspectives, g) Road safety and maintenance, h) Strengthening roadside air quality monitoring and assessment, and, i) Strengthening the knowledge base, awareness, and public participation.

The shift in focus towards environmental sustainability means that analytical attention must now also be paid to gendered mobility in relation to the environment and technology. Studies of how women and men relate to the physical environment, urban design, city density, accessibility issues concerning environmental sustainability (e.g. energy, pollution, climate) are necessary to enhance current knowledge. In line with the discussions the Asian Development Bank launched a Gender Tool Kit in 2013, and the UN presented the Sustainable Development Goals in 2015 where the different needs of women and men were recognized in the following way: "unfortunately, the transportation systems in cities are often built to address the needs of men with little consideration of the needs of women. When compared to men, women move about cities at different times, for different reasons, in different ways, and have fewer financial resources; they are less able to afford many of the transportation options available to them". The notion of empowerment is helpful in understanding how urban mobility is gendered: "to be disempowered means to be denied choice, while empowerment refers to the processes by which those who have been denied the ability to make choices acquire such ability" (Kabeer, 2005). The concepts of empowerment, risk and agency may therefore be employed to inspire change that will result in the 'equal access' and sustainable transport systems demanded by the United Nations Intergovernmental Panel on Climate Change (2014).

Thus we find that the international and global perspectives all agree about the importance of supporting women's mobility and equal access to the city. The next section presents some conclusions and points at (some) future issues.

\section{Conclusions}

Understanding the way in which mobility is gendered is critical for finding ways to improve women's position in society and for creating equality in Asia's growing cities. The lack of equality in the transport sector has been a problem for decades and several initiatives have been launched to enhance women's influence and involvement, though they have largely failed and masculine norms persist.

Top-down, international and national perspectives focus on women's economic role in poverty reduction, whereas the sustainability discourse stresses equity, social cohesion and livable cities. The Sustainable Development Goal Number 11 highlights the demand to "make cities inclusive, safe, resilient and sustainable".
It builds upon work carried out in several parts of the world, including Asia, by organizations such as UNCRD and others. The messages from the World Bank and the UN presented above alert us to the need for gendersensitive transport policies that also respond to sustainability goals. Researchers, economists and political organizations are already looking at how to design such policies but the concept of sustainable transport has proven difficult to put into action and the local dimensions of transport equality are complex. This means that it remains unclear exactly how gender-sensitive policies should be shaped in order to meet women's mobility needs in rapidly developing Asian cities.

Overall, top-down initiatives to mainstream gender policies tend to be similar. Further research is required to clarify the relationship between women's participation in the development of cities and societies, their mobility patterns and the gender norms that affect them in growing Asian cities. More in-depth knowledge about the conditions for women who commute or make other kinds of journeys in cities is more likely to help bring about desirable long-term change than simply implementing practices of gender separation, such as 'pink solutions', which increase women's safety temporarily. Universal policies for increasing equality should be favoured over exclusionary practices, which may simply lead to future conflict instead (Kabeer, 1999, 2002).

Because of their global or national nature, big economic and political institutions have largely failed to respond to women's mobility needs at the local level. Awareness is gradually growing about the importance of local conditions and the Bali Declaration is unique in that it builds on a comprehensive understanding about challenges related to climate change, environmental issues and basic social needs such as access to work, services and opportunities in different contexts. The methods used in gender studies inquire into geographical and social variation and explore local views of women's mobility. Beyond the question of economic policy remain that of rights and the ability to voice concerns and exercise choice. More inclusive urban access would enhance conditions for women and enable them to make choices according to their needs. The policies of development banks for women's roles in modernizing cities are thus litmus tests for 'true' empowerment (Cornwall \& Brock, 2005).

Contributions from research and from financial and political institutions may together help promote the development of gender-sensitive transport policies. In this way, science and policy may cross-pollinate one another and result in well-informed decisions.

\section{Acknowledgements}

Thanks to the UNCRD in Nagoya for guiding the development of the Asian Environmentally Sustainable Transport Initiative (EST Forum) since 2004. Thanks to 
Titony Ralainarivo-Rollin and his Master Thesis Mobility and Empowerment in Delhi, and to the anonymous reviewers for their comments. Thanks also to Alexandra Kent for language polishing.

\section{Conflict of Interests}

The author declares no conflict of interests.

\section{References}

Adeel, M., Yeh, A. G., \& Zhang, F. (2016). Transportation disadvantage and activity participation in the cities of Rawalpindi and Islamabad, Pakistan. Transport Policy, 47, 1-12.

African Development Bank, \& African Development Fund. (2001). The gender policy. African Development Bank \& African Development Fund. Retrieved from http://www.afdb.org

Asian Development Bank. (2013). Gender tool kit: Transport. Asian Development Bank. Retrieved from http://www.adb.org/documents/gender-tool-kit-tra nsport-maximizing-benefits-improved-mobility-all

Asian Development Bank. (2014). Issues, challenges, and ADB's approach. Asian Development Bank. Retrieved from http://www.adb.org/themes/urban-developme $\mathrm{nt} /$ issues

Bali Declaration. (2013). Vision three zeros: Zero congestion, zero pollution, and zero accidents towards next generation transport systems in Asia. Nagoya, Japan: United Nations Centre for Regional Development. Retrieved from http://www.uncrd.or.jp

Bisan, S. (2010). International workshop on gender, economic integration and cross-border road infrastructure development: Poverty and mobility in the context of Asia. Gender, Technology and Development, 14, 279-286.

Camstra, R. (1996). Commuting and gender a life style perspective. Journal of Urban Studies, 33, 283-300.

Carruthers, R., Dick, M., \& Faukar, A. (2005). Affordability of public transport in developing countries (Transport Paper 3). Washington: World Bank.

Chant, S., \& Sweetman, C. (2012). Fixing women or fixing the world? 'Smart economics', efficiency approaches, and gender equality in development. Gender \& Development, 20(3), 517-529.

Cornwall, A. (2004). New democratic spaces? IDS Bulletin, 35(2), 1-10.

Cornwall, A., \& Brock, K. (2005). What do buzzwords do for development policy? A critical look at 'participation', 'empowerment' and 'poverty reduction. Third World Quarterly, 26(7), 1043-1060.

Cornwall, A., \& Molyneux, M. (2006). The politics of rights: Dilemmas for feminist praxis. An introduction. Third World Quarterly, 27(7), 1175-1191.

Du, J., \& Kurz, J. (2003). Integrating gender into World Bank financed transport programs, case study China
(Working Paper No. 34493). Washington: World Bank.

Eyben, R. (2004). The road not taken: International aid's choice of Copenhagen over Beijing. Geneva, Switzerland: UNRISD.

Eyben, R. (2012). Fellow travellers in development. Third World Quarterly, 33(8), 1405-1421.

Gannon, C., \& Liu, Z. (1997). Poverty and transport (TWU30 Discussion Paper Transport Division). Washington: World Bank.

Grieco, M. (2009). Gender and transport: Transaction costs, competing resources and transport power, gender and social change in Africa. Cambridge, UK: Cambridge Scholars Publishing.

Grieco, M., \& Urry, J. (2011). Mobilities: New perspectives on transport and society. Farnham, UK: Ashgate.

Hanson, S. (1996). The geography of urban transportation. New York: The Guilford Press.

Hanson, S. (2010). Gender and mobility: New approaches for informing sustainability. Gender, Place \& Culture: A Journal of Feminist Geography, 17(1), 5-23.

Hanson, S., \& Pratt, G. (1995). Gender, work and space. New York: Routledge.

Harvey, D. (1978). Social justice and the city. Baltimore, MD: John Hopkins Press.

Jagori \& UN Women. (2011). Safe cities free of violence against women and girls' initiative (Report of the Baseline Survey Delhi 2010). New Delhi: Signate G Press.

Kabeer, N. (1999) The conditions and consequences of choice: Reflections on the measurement of women's empowerment (UNRISD Discussion Paper No. 108). Geneva: United Nations Research Institute for Social Development.

Kabeer, N. (2001). Conflict over credit: Re-evaluating the empowerment potential of loans to women in rural Bangladesh. World Development, 29(1), 63-84.

Kabeer, N. (2002). Reflections on the measurement of women's empowerment in Discussing Women's Empowerment-Theory and Practice. In B. Sevefjord, \& B. Olsson (Eds.), Sida studies no. 3 (pp. 17-57). Stockholm. Retrieved from www.sida.se

Kabeer, N. (2005). Gender equality and women's empowerment: A critical analysis of the third millennium development goal 1. Gender \& Development, 13(1), 13-24.

Khan, R. (2009). How safe are the walkers in Dhaka City? Paper presented at the 45th ISOCARP Congress 2009, Porto, Portugal.

Ki-Moon, B. (2013). Special message from UN secretary general. United Nations Centre for Regional Development. Retrieved from http://www.uncrd.or.jp

Kronsell, A. (2005). Gendered practices in institutions of hegemonic masculinity. International Feminist Journal of Politics, 7(2), 280-298.

Kronsell, A., Smidfelt Rosqvist, L., \& Winslott Hiselius, L. 
(2015). Achieving climate objectives in transport policy by including women and challenging gender norms: The Swedish case. International Journal of Sustainable Transportation. doi:10.1080/15568318. 2015.1129653

Law, R. (1999). Beyond 'women and transport': Towards new geographies of gender and daily mobility. Progress in Human Geography, 23(4), 567-588.

Lefebvre, H. (1982). Stadens som rättighet. Lund, Sweden: Bokomotiv Förlag.

Lindén, A. L. (1994). Människa och miljö. Stockholm, Sweden: Carlssons.

Litman, T. (2006). Cities connect: How urbanity helps achieve social inclusion objectives. Paper presented at the Metropolis Conference, Toronto. Retrieved from http://www.vtpi.org/citiesconnect.pdf

Lohani, B. (2010). Asian countries call for actions to attain 10-year goals for more sustainable transport. United Nations Centre for Regional Development. Retrieved from http://www.uncrd.or.jp

Longwe, S. H. (1995). Gender awareness: The missing element in the third world development program. In E. March \& T. Wallace (Eds.), Changing perception: New writings on gender and development. Oxford, UK: Oxfam.

Lucas, K. (2004). Transport and social exclusion: A survey of the group of seven nations. London: FIA Foundation, Transport Studies Group.

Marchand, M. (2009). The future of gender and development after 9/11: Insights from postcolonial feminism and transnationalism. Third World Quarterly, 30(5), 921-935.

Moser C. (1989). Gender planning in the Third World: Meeting practical and strategic gender needs. World Development, 17(11), 179-185.

Moser, C. (2006). Has gender mainstreaming failed? International Feminist Journal of Politics, 7(4), 576-590.

Moser, C., \& Peake, L. (1987). Women, human settlements and housing: A conceptual framework for analysis and policy-making. London: Tavistock.

Moser, C., \& Moser, A. (2005). Gender mainstreaming since Beijing: A review of success and limitations in international institutions. Gender \& Development, 13(2), 11-22.

Paterson, M. (2007). Automobile politics: Ecology and cultural political economy. Cambridge, UK: Cambridge University Press.

Peters, D. (2001). Gender and transport in less developed countries (A background paper in preparation for CSD-9). London: UNED Forum Organisation.

Peters, D. (2013). Gender and sustainable urban mobility (Thematic study prepared for Global Report on Human Settlements). Nairobi, Kenya: UNHABITAT. Retrieved from http: www.unhabitat.org/grhs/2013

Raje, F., Grieco, M., Hine, J., \& Preston, J. (2004). Transport, demand management and social inclusion: The need for ethnic perspectives. Aldershoy, UK:
Ashgate.

Roberts, A., \& Soederberg, S. (2012). Gender equality as smart economics? A critique of the 2012 world development report. Third World Quarterly, 33(5), 949968.

Rosenbloom, S. (2004). Understanding women's and men's travel patterns: The research challenge in Women's issues in transportation report of a conference. In Volume 1: Conference overview and plenary papers (pp. 7-28). Washington: Transportation Research Board of the National Academies. Retrieved from http://onlinepubs.trb.org/onlinepubs/conf/CP3 5v1.pdf

Rowlands, J. (1997). Questioning empowerment: Working with women in Honduras. Oxford, UK: Oxfam.

Roychowdhury, P. (2013). "The Delhi gang rape": The making of international causes. Feminist Studies, 39(1), 282-292.

Short, J. R., \& Pinet-Peralta, L. M. (2010). No accident: Traffic and pedestrians in the modern city. Mobilities, 5(1), 41-59.

SIDA. (2005). Guidelines for gender mainstreaming. Stockholm, Sweden: SIDA.

SIKA Statistics. (2007). RES 2005-2006. Swedish national travel survey, 19. Stockholm, Sweden: SIKA Statistics.

Tacoli, C., \& Satterthwaite, D. (2013). Gender and urban change. Environment and Urbanization, 25(3), 3-5.

Tara, S. (2011, December 17). Private space in public transport: Locating gender in the Delhi metro. Economic \& Political Weekly, 46(51). Retrieved from http://www.epw.in/date?e

Thynell, M. (2003). The unmanageable modernity. An explorative study of motorized mobility in development (PhD. Thesis). University of Gothenburg, Sweden.

Thynell, M., Punte, S., \& Arora, A. (2009). Social impact assessment for public transport in cities: An approach for practitioners involved in the planning, design and implementation of public transport systems (TA 6291). Manila, Philippines: ADB Report.

Thynell, M., Tran, H. A., \& Schlyter, A. (2010). Sustainable urban transport and social justice: Case studies in Ha Noi and Xi'an. Stockholm, Sweden: SIDA.

Thynell, M., \& Wolmar, C. (2014). Access and mobility in cities. Stockholm, Sweden: Capito AB.

Tiwari, G. (2014). Planning and designing transport systems to ensure safe travel for women (Discussion Paper 2014-04). Paris, France: International Transport Forum, OECD.

Turner, J. (2012). Urban mass transit, gender planning protocols and social sustainability-The case of Jakarta. Research in Transportation Economics, 34, 4853.

United Nations. (2015). Resources for speakers on global issues. United Nations. Retrieved from http://www.un.org/en/globalissues/briefingpapers/ population/vitalstats.shtml 
United Nations Chronicle. (2015). Goal 11-Cities will play an important role in achieving the SDGs. UNCronichle. Retrieved from http://unchronicle.un.org/ article/goal-11-cities-will-play-important-role-achievi ng-sdgs

United Nations, Department of Economic and Social Affairs, Population Division. (2014). World Urbanization Prospects: The 2014 Revision, Highlights (ST/ESA/ SER.A/352). New York: United Nations.

United Nations Development Programme. (2013). Gender and Poverty Reduction. United Nations Development Programme. Retrieved from http: www undp.org

United Nations Intergovernmental Panel on Climate Change. (2014). The $5^{\text {th }}$ report: Mitigation of climate change. Retrieved from http://www.ipcc.ch/report/ ar5/wg3/

Uteng, P.T. (2011). Gender and mobility in the developing world (World Development Report 2012, Back- ground Paper. Gender Equality and Development). Washington: The World Bank.

Vasconcellos de Alcantara, E. (2001). Urban transport, environment and equity: The case for developing countries. London: Earthscan.

Wang, L., \& Qin, P. (2015). Distance to work in Beijing: Institutional reform and bargaining power. Urban Studies. doi:10.1177/0042098015620358

Wismans, J., Skogsmo, I., Nilsson-Ehle, A., Lie, A., Thynell, M., \& Lindberg, G. (2015). Commentary: Status of road safety in Asia. Journal of Traffic Injury Prevention, 17(3), 217-225.

Wolfowitz, P. (2006). Gender equality as smart economics: Gender action plan. Washington: World Bank.

World Bank. (2010). Making transport work for women and men: Tools for task teams. Washington, DC: World Bank. Retrieved from https://openknowledge. worldbank.org/handle/10986/12555

\section{About the Author}

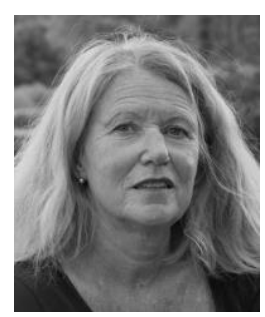

Marie Thynell, Associate Professor in Peace and Development Research, is a social scientist in the area of Development Research and Urban Studies. She focusses on local expressions of global change such as sustainable city development, global cities, access and mobility, social equity and gender perspectives in developing, as well as developed cities. Thynell has extensive experience from interdisciplinary approaches and from learning in collaboration with stakeholders. Thynell has carried out case studies in Xì an, Ha Noi, Delhi, Petrozavodsk, Skopje, Rome, Copenhagen, Brasília, Jakarta, Santiago, Beijing and Hong Kong. 